UDC 595.773.1

\title{
First records of Dolichopodidae (Diptera) from Bastak Nature Reserve, Russia
}

\author{
I. Ya. Grichanov
}

All-Russian Institute of Plant Protection, Podbelskogo 3, Pushkin, 196608, Saint Petersburg, Russia

\begin{abstract}
Author
Igor Ya. Grichanov

E-mail: grichanov@mail.ru

SPIN: 1438-5370

Scopus Author ID: 8672518800

ResearcherID: A-1406-2013

ORCID: 0000-0002-7887-7668
\end{abstract}

Copyright: () The Author (2021). Published by Herzen State Pedagogical University of Russia. Open access under CC BY-NC License 4.0.

\begin{abstract}
A new material of Dolichopodidae has been recently collected in Bastak Nature Reserve, and includes 8 species (all species are found for the first time in the Reserve and in the Jewish Autonomous Region). In total, 20 species are reported in this region, which apparently makes up $20-25 \%$ of actual Dolichopodidae regional fauna. 11 species found in the Jewish Region are only reported in the East Palaearctic Region. Some of them are rare, known earlier only in Primorye (Dolichopus longisetus, Gymnopternus nemorum, Medetera stylata and Rhaphium nuortevai). This paper also provides a distribution pattern for each collected species.
\end{abstract}

Keywords: Dolichopodidae, Russian Far East, Jewish Autonomous Region, Bastak Nature Reserve, new records.

\section{Первые указания Dolichopodidae (Diptera) из заповедника Бастак, Россия}

\author{
И. Я. Гричанов \\ Всероссийский институт защиты растений, шоссе Подбельского, А. 3, г. Пушкин, 196608, \\ Санкт-Петербург, Россия
}

\section{Сведения об авторе \\ Гричанов Игорь Яковлевич \\ E-mail: grichanov@mail.ru \\ SPIN-KOA: 1438-5370 \\ Scopus Author ID: 8672518800 \\ ResearcherID: A-1406-2013 \\ ORCID: 0000-0002-7887-7668}

Права: ( Автор (2021). Опубликовано Российским государственным педагогическим университетом им. А. И. Герцена. Открытый Аоступ на условиях Аицензии СС BY-NC 4.0.
Аннотация. Материал по семейству Dolichopodidae впервые собран в Государственном природном заповеднике «Бастак»; новые указания вкАючают 8 видов (все найдены впервые в Еврейской автономной области). Всего в области отмечено 20 виАов, что, по-виАимому, составляет 20-25\% региональной фауны Dolichopodidae. Из них 11 видов распространены только в Восточной Палеарктике. Некоторые виды явцяются реАкими, известными ранее Аишь в Приморье (Dolichopus longisetus, Gymnopternus nemorum, Medetera stylata и Rhaphium nuortevai). В статье приведено также общее распространение Аля кажАого отловленного виАа.

Ключевые слова: Dolichopodidae, Аальний Восток России, Еврейская автономная область, заповедник Бастак, новые указания. 


\section{Introduction}

Jewish Autonomous Region, or Oblast (JAO) is located in the Russian Far East, bordering Khabarovskii Krai and Amurskaya Oblast in Russia and Heilongjiang province in China, with the poorly studied fauna of long-legged flies, regarding especially protected areas of the Region. The Bastak Nature Reserve's main territory covers the south-eastern ridges of Bureya Massif and the northern outskirts of the Middle-Amur Lowland. It is located in the Ussuri Broadleaf and Mixed Forests ecoregion and borders with the Amur Meadow Steppe in the South (see Ecoregions 2017). The Reserve is crossed by a network of small rivers with a few small lakes (Averin et al. 2012).

The first data on 12 dolichopodid species found on the JAO territory in 1991 was published by author of this paper (Grichanov 2006). This material was collected from environs of Amurzet village on Amur River shore in the south-western part of the Region. None dolichopodid fly was known from other JAO territories. There were later some nomenclatural changes for the published names. Hercostomus arcticus Yang, 1996 was placed in synonymy with Hercostomus flaveolus Negrobov et Chalaya, 1987 (Negrobov et al. 2016), which was transferred to the genus Poecilobothrus Mik, 1878 by Grichanov (2020). Hercostomus ussurianus Stackelberg, 1933 was transferred to the genus Gymnopternus Loew, 1857 by the same author (Grichanov 2020).

The material for this study was collected by the collaborator of the Reserve A. A. Averin by the use of standard Malaise trap method, fixed in $76 \%$ ethanol, then dried and mounted on pins; it will be deposited at the Zoological Institute of the Russian Academy of Sciences, Saint Petersburg. Females are not sorted as they could hardly be distinguished from females of closely related species inhabiting the Far East.

New records for 8 species are listed below, collected about $15 \mathrm{~km}$ north of the city of Birobidzhan and labelled as follows: Jewish Region, Bastak Nature Reserve, $48.9^{\circ} \mathrm{N}$, $133.0^{\circ} \mathrm{E}$. These data are not repeated in the text. The information on the global distribution for each species follows Grichanov (2017). The type localities are provided and the country lists are arranged alphabetically. The words "Region" (Oblast) and "Territory" (Krai) are omitted from the list of Russian regions. Remarks are provided where deemed necessary.

\section{New records}

Chrysotus nudisetus Negrobov et Maslova, 1995

Material examined. $5 \hat{\circ}, 1-5.07 .2020 ; 11-$ 24.08.2020.

Distribution. Type locality: Russia, Sakhalin, Anivskii distr. Palaearctic: Japan, Russia (Chukotka, Khabarovsk, Magadan, Primorye, Sakhalin, Yakutia).

\section{Dolichopus bonsdorffi Frey, 1915}

Material examined. $1 \hat{\jmath}, 1-5.07 .2020$.

Distribution. Type locality: Finland: "westliche Lappland: Monio, in der Nahe des Fjeldes Olostunturi”. Palaearctic: China (Heilongjiang), Estonia, Finland, Sweden, Russia (Altai Rep., Karelia, Khabarovsk, Leningrad).

Notes. Negrobov (1991) included "Maritime Territory" (= Primorye) into the species area without material provided. Nevertheless, the species may be found in this territory in future.

Dolichopus nataliae Stackelberg, 1930

Material examined. $3 \hat{\jmath}, 1-21.06 .2020$; 1-5.07.2020.

Distribution. Type localities: Russia, Primorye, "Spassk-Yakovlevka road at Ugodinza (= Pyatigorka) River; Tigrovaya”. Palaearctic: Russia (Khabarovsk, Magadan, Primorye, Yakutia).

Dolichopus setimanus Smirnov, 1948

Material examined. 1 $\delta, 11-24.08 .2020$.

Distribution. Type locality: Russia, Primorye, Okeanskaya, near Vladivostosk. Palaearctic: Russia (Blagoveshchensk, Khabarovsk, Primorye, Sakhalin including Kuril Islands, Zabaikalye).

Dolichopus ussuriensis Stackelberg, 1930

Material examined. $13 \hat{\sigma}, 1-21.06 .2020$; 1-5.07.2020. 
Distribution. Type localities: Russia, Primorye: "Majkhe (= Shtykovo), near Shkotovo, Tigrovaya, Spassk-Yakovlevka, river Ugodinza (= Pyatigorka)". Palaearctic: Russia (Blagoveshchensk, Khabarovsk, Primorye).

Gymnopternus aerosus (Fallén, 1823)

Material examined. 2 $\hat{\jmath}, 1-5.07 .2020$.

Distribution. Type locality: not given (Sweden). Palaearctic: Abkhazia, Austria, Belarus, Belgium, Bulgaria, Czechia, Denmark, Estonia, Finland, France, Germany, Hungary, Ireland, Italy, Japan, Kazakhstan, Latvia, Lithuania, Mongolia, Netherlands, Norway, Poland, Romania, Russia (Adygea, Alania, Arkhangelsk, Kaliningrad, Karelia, Karachai-Cherkessia, Krasnodar, Leningrad, Lipetsk, Mordovia, Moscow, Murmansk, Novgorod, Pskov, Tatarstan, Voronezh, "Ural”, Buryatia, Irkutsk, Khantia-Mansia, Primorye, Sakhalin), Slovakia, Sweden, Tajikistan, UK, Ukraine; Oriental: Taiwan.

Gymnopternus nemorum (Smirnov et Negrobov, 1977)

Material examined. $3 \hat{\jmath}, 1-5$ July 2020; 11-24 August 2020.

Distribution. Type locality: Russia, Primorye, Partisansk. Palaearctic: Russia (Primorye).

Medetera stylata Negrobov in Negrobov et Stackelberg, 1972

Material examined. $1 \hat{\jmath}, 1-21.06 .2020$.

Distribution. Type locality: Russia, Primorye: "Maikhe (= Artyomovka River), nähe von Shkotovo, Ussuri-Gebiet”. Palaearctic: Russia (Primorye).

\section{Acknowledgements}

The author is sincerely grateful to Dr. Igor Shamshev (ZIN) for his kindness in providing specimens for study. The work was funded by RFBR and NSFC according to the research project No. 20-54-53005. Drs. Nikita Vikhrev (ZMMU) and Igor Shamshev (ZIN) kindly commented on earlier draft of the manuscript.

\section{Appendix}

A checklist of Dolichopodidae species known from the Jewish Autonomous Region. An asterisk (*) designates species reported from Bastak Nature Reserve.
1. Campsicnemus picticornis (Zetterstedt, 1843)

2. Chrysotus degener Frey, 1917

3. Chrysotus nudisetus Negrobov et Maslova, 1995*

4. Dolichopus agilis Meigen, 1824

5. Dolichopus bonsdorffi Frey, 1915*

6. Dolichopus eurypterus Gerstäcker, 1864

7. Dolichopus linearis Meigen, 1824

8. Dolichopus longisetus Negrobov, 1977

9. Dolichopus nataliae Stackelberg, 1930*

10. Dolichopus setimanus Smirnov, 1948*

11. Dolichopus ussuriensis Stackelberg, $1930 *$

12. Dolichopus varians Smirnov, 1948

13. Dolichopus xanthopyga Stackelberg, 1930

14. Gymnopternus aerosus (Fallén, 1823)*

15. Gymnopternus nemorum (Smirnov et Negrobov, 1977)*

16. Gymnopternus ussurianus (Stackelberg, 1933)

17. Medetera stylata Negrobov in Negrobov et Stackelberg, 1972*

18. Poecilobothrus flaveolus (Negrobov et Chalaya, 1987)

19. Rhaphium micans (Meigen, 1824)

20. Rhaphium nuortevai Negrobov, 1977

\section{Conclusion}

As a result of this study, 8 Dolichopodidae species are recorded in Bastak Nature Reserve and JAO for the first time. In total, 20 species are reported in this Region, which apparently makes up 20-25\% of actual Dolichopodidae regional fauna as compared with the much better studied Primorye and Khabarovskii Territory of Russia. All species newly collected in Bastak Nature Reserve are new for the Jewish Autonomous Region. Most species (11) found in the JAO are reported only in the East Palaearctic Region. Some of them are rare, known at present in JAO and Primorye (Dolichopus longisetus, Gymnopternus nemorum, Medetera stylata and Rhaphium nuortevai). Such species as Chrysotus degener and Poecilobothrus flaveolus occur in both East Palaearctic and Orient. Seven species are Trans-Palaearctic, either boreal or polyzonal. 


\section{References}

Averin, A. A., Antonov, A. I., Barbarich, A. A. et al. (2012) Zhivotnyi mir zapovednika "Bastak" [Fauna of Bastak Nature Reserve]. Blagoveshchensk: Blagoveshchensk State Pedagogical University Publ., 242 p. (In Russian)

Ecoregions. (2017) [Online]. Available at: https://ecoregions2017.appspot.com (accessed 10.12.2020). (In English)

Grichanov, I. Ya. (2006) A checklist of Dolichopodidae (Diptera) of Khabarovsk Territory and Jewish Autonomous Region (Russia). An International Journal of Dipterological Research, vol. 17, no. 3, pp. 167-175. (In English)

Grichanov, I. Ya. (2017) Alphabetic list of generic and specific names of predatory flies of the epifamily Dolichopodoidae (Diptera). $2^{\text {nd }}$ ed. Saint Petersburg: All-Russian Research Institute of Plant Protection Publ., 563 p. (Plant Protection News. Supplements. Iss. 23). https://www.doi.org/10.5281/ zenodo.884863 (In English)

Grichanov, I. Ya. (2020) New records of Dolichopodidae (Diptera) from Russian Primorye and notes on some Chinese species. Russian Entomological Journal, vol. 29, no. 4, pp. 432-438. https://www.doi. org/10.15298/rusentj.29.4.12 (In English)

Negrobov, O. P., Kumazawa, T., Tago, T., Satô, M. (2016) New species of Hercostomus Loew, 1857 (Dolichopodidae, Diptera) from Japan. Zootaxa, vol. 4158, no. 1, pp. 65-80. https://doi.org/10.11646/ zootaxa.4158.1.3 (In English)

For citation: Grichanov, I. Ya. (2021) First records of Dolichopodidae (Diptera) from Bastak Nature Reserve, Russia. Amurian Zoological Journal, vol. XIII, no. 3, pp. 401-404. https://www.doi.org/10.33910/2686-9519-2021-133-401-404

Received 10 May 2021; reviewed 26 May 2021; accepted 1 June 2021.

Аля цитирования: Гричанов, И. Я. (2021) Первые указания Dolichopodidae (Diptera) из заповеАника Бастак, Россия. Амурский зоологический журнал, т. XIII, № 3, с. 401-404. https://www.doi.org/10.33910/2686-95192021-13-3-401-404

Получена 10 мая 2021; прошиа рецензирование 26 мая 2021; принята 1 июня 2021. 